\title{
Nowe znaki graficzne na urządzeniach dystrybucyjnych paliw silnikowych i pojazdach
}

\section{New graphic signs on fuel distribution devices and vehicles}

\author{
Martynika Pałuchowska, Zofia Błaszkiewicz \\ Instytut Nafty i Gazu - Państwowy Instytut Badawczy
}

\begin{abstract}
STRESZCZENIE: W artykule podano genezę i sposób wprowadzania oraz wygląd obowiązkowego oznakowania paliw na urządzeniach dystrybucyjnych, pojazdach i w instrukcjach obsługi. Podstawą tych działań jest wdrażanie do porządku prawnego państw członkowskich UE dyrektywy 2014/94/UE w sprawie rozwoju infrastruktury paliw alternatywnych. Wdrożenie tej dyrektywy, poza zapewnieniem rozwoju infrastruktury dla tych paliw, ma zapewnić także właściwą, jasną i spójną informację dla klientów odnośnie do kompatybilności ich pojazdu z właściwym materiałem pędnym (paliwa ciekłe, gazowe, energia elektryczna). Według dyrektywy do paliw alternatywnych zalicza się energię elektryczną, wodór, biopaliwa, paliwa syntetyczne i parafinowe, gaz ziemny, w tym biometan, sprężony gaz ziemny - CNG, skroplony gaz ziemny - LNG oraz gaz płynny LPG. W dalszej części artykułu poinformowano o poszczególnych rodzajach paliw silnikowych o znormalizowanej jakości obecnych na rynku europejskim, które podlegają nowemu obligatoryjnemu oznakowaniu. Przytoczono aktualne wydania europejskich norm określających jakość tych rodzajów paliw silnikowych, zawierające odwołanie do normy europejskiej EN 16942:2016-11. Norma ta została opracowana przez Europejski Komitet Normalizacyjny (CEN) jako wsparcie wdrażania dyrektywy 2014/94/UE. Prace nad projektem normy rozpoczęły się w sierpniu 2015 r. Został powołany Komitet Techniczny CEN/TC 441 Fuel Labelling. Zakres prac obejmował opracowanie projektu normy zapewniającej zharmonizowany identyfikator dystrybuowanych paliw ciekłych i gazowych. Podczas prac CEN współpracował z Komisją Europejską oraz zainteresowanymi stronami (między innymi: producentami paliw, pojazdów, urządzeń dystrybucyjnych, władzami publicznymi, przedstawicielami konsumentów). W celu możliwie jednoczesnego wdrożenia postanowień dyrektywy na podstawie EN 16942:2016 we wszystkich krajach europejskich instytucje europejskie zorganizowały warsztaty na temat nowego oznakowania. Wdrożenie postanowień dyrektywy do porządku prawnego Polski nastąpiło poprzez przygotowanie i publikację Ustawy z dnia 11 stycznia 2018 r. o elektromobilności i paliwach alternatywnych. Do zbioru Polskich Norm norma europejska została włączona jako PN-EN 16942:2016-11. W artykule przytoczono zapisy tej normy, określającej sposób znakowania poszczególnych rodzajów paliw. Ponadto podano przykłady umieszczania nowego oznakowania zarówno na dystrybutorach paliw, pistoletach wydawczych, jaki i korkach wlewu paliwa w pojazdach oraz w instrukcjach obsługi pojazdów.
\end{abstract}

Słowa kluczowe: paliwa, pojazdy, znaki graficzne, normalizacja.

ABSTRACT: The article describes the genesis and the method of introducing as well as the appearance of mandatory fuel labelling on distribution devices, vehicles and in manuals. The basis thereof is the implementation of Directive 2014/94/EC on the deployment of alternative fuels infrastructure. The implementation of this directive, apart from ensuring the development of the infrastructure for these fuels, is also intended to provide appropriate, clear and consistent information to customers regarding the compatibility of their vehicle with the relevant propellant (liquid fuels, gas, electricity). According to the directive, alternative fuels include electricity, hydrogen, biofuels, synthetic and paraffin fuels, natural gas, including biomethane, compressed natural gas - CNG, liquefied natural gas - LNG and LPG. The article also contains information about different types of motor fuels present on the European market, which are subject to a new mandatory labeling. The current editions of European standards defining the quality of these types of motor fuels, which refer to EN 16942: 2016-11 Standard, have been cited. This standard was developed by CEN to support the implementation of Directive 2014/94/EC. Work on developing a draft standard began in August 2015. The CEN/TC441 Fuel Labelling Technical Committee was established. The scope of work included the development of a draft standard providing a harmonized identifier of distributed liquid and gas fuels. During the work, CEN cooperated with the EC and interested parties (including producers of fuels, vehicles, distribution devices, public authorities, consumer representatives). In order to implement the provisions of the directive based on EN 16942:2016 in all European countries as simultaneously as possible, the European institutions organized workshops on the new labelling. The provisions

Autor do korespondencji: M. Pałuchowska, e-mail: martynika.paluchowska@inig.pl

Artykuł nadesłano do Redakcji 10.05.2019 r. Zatwierdzono do druku 16.09.2019 r. 
of the directive were implemented into the Polish legal system through publication of the Act dated January 11, 2018 on Electromobility and Alternative Fuels. Meanwhile, the European Standard was incorporated into the collection of Polish Standards as PN-EN 16942: 2016-11. The article cites the PN-EN 16942:2016-11 Standard, which defines the method of different types of fuels labelling. Moreover, examples of placing new labelling on distribution dispenser, nozzle, filler cap and in manuals are presented.

Key words: fuels, vehicles, graphic signs, standardization.

\section{Dyrektywa 2014/94/UE w sprawie rozwoju infrastruktury paliw alternatywnych (DAFI)}

Działania Unii Europejskiej w obszarze promocji wykorzystywania odnawialnych źródeł energii w transporcie w celu zastępowania tą energią energii pochodzącej ze źródeł kopalnych (tj. ropy naftowej) spowodowały wzrost liczby rodzajów paliw na rynku europejskim. Dla wielu z tych paliw opracowano wymagania jakościowe stanowiące wypracowany konsens między wymaganiami producentów paliw i producentów pojazdów a wymaganiami związanymi z zachowaniem czystego środowiska naturalnego, przy uwzględnieniu także wymagań zrównoważonego rozwoju.

W związku z dużą liczbą rodzajów paliw, w tym paliw alternatywnych, Parlament Europejski i Rada Europy na wniosek Komisji Europejskiej przyjęły dyrektywę 2014/94/UE w sprawie rozwoju infrastruktury paliw alternatywnych (Dyrektywa 2014/94/UE), zwaną popularnie DAFI. Wdrożenie tej dyrektywy do porządku prawnego krajów członkowskich, poza zapewnieniem rozwoju infrastruktury dla tych paliw, ma także zapewnić właściwą, jasną i spójną informację dla klientów na temat kompatybilności ich pojazdu z właściwym materiałem pędnym (paliwa ciekłe, gazowe, energia elektryczna).

W zapisach preambuły wyżej wspomnianej dyrektywy odnośnie do problemów związanych z różnorodnością paliw stwierdzono: „(49) Mając na uwadze rosnącą różnorodność rodzajów paliw [...], konieczne jest udostępnianie użytkownikom pojazdów jasnych i łatwo zrozumiałych informacji dotyczących paliw dostępnych w punktach tankowania paliw oraz zgodności ich pojazdów z różnymi paliwami [...]”.

Artykuł 7 tejże dyrektywy podaje następujące wymagania: „1. Bez uszczerbku dla dyrektywy 2009/30/WE państwa członkowskie zapewniają udostępnienie właściwych, spójnych i jasnych informacji dotyczących pojazdów silnikowych [...] Informacje takie muszą być dostępne w instrukcjach obsługi pojazdów silnikowych, w punktach tankowania paliwa i punktach ładowania, na pojazdach silnikowych oraz w placówkach handlu pojazdami silnikowymi na ich terytorium. Niniejszy wymóg ma zastosowanie do wszystkich pojazdów silnikowych [...] wprowadzone na rynek po dniu 18 listopada 2016 r.”.

W kolejnej części artykułu 7, w aspekcie informacji dla klienta, odniesiono się do konieczności oparcia się na odpowiednich przepisach oznakowania paliw i pojazdów: „2. Dostarczanie informacji, o których mowa w ust. 1, oparte jest na przepisach dotyczących etykietowania w odniesieniu do zgodności paliw z normami europejskich organizacji normalizacyjnych określającymi specyfikacje techniczne paliw. W przypadku gdy te normy przewidują informacje w formie graficznej, w tym kody barwne, taka forma graficzna musi być prosta i łatwa do zrozumienia i jest umieszczana w sposób wyraźnie widoczny:

a) na odpowiednich dystrybutorach $i$ ich pistoletach we wszystkich punktach tankowania paliwa, od dnia, w którym paliwa zostaną wprowadzone na rynek;

b) na wszystkich korkach wlewu paliwa pojazdów silnikowych, dla których zaleca się to paliwo i które mogą używać tego paliwa, lub w bezpośrednim pobliżu tych korków, a także w instrukcji użytkowania pojazdów silnikowych, w przypadku gdy te pojazdy silnikowe zostają wprowadzone na rynek po dniu 18 listopada 2016 r.".

Celem dyrektywy (Dyrektywa 2014/94/UE) jest wspieranie szerokiego rozwoju rynku paliw alternatywnych, a jak zaznaczono w dyrektywie, obecnie w UE brak jest zharmonizowanego rozwoju infrastruktury paliw alternatywnych, co stanowi przeszkodę w osiąganiu odpowiednich korzyści. Dyrektywa ta definiuje paliwa alternatywne w art. 2 ust. 1 jako: „1) «paliwa alternatywne» oznaczają paliwa lub źródła energii, które służą, przynajmniej częściowo, jako substytut dla pochodzących z surowej ropy naftowej źródeł energii w transporcie i które mogą potencjalnie przyczynić się do dekarbonizacji transportu i poprawy ekologiczności sektora transportu. Obejmują one między innymi:

- energię elektryczną,

- wodór,

- biopaliwa zdefiniowane w art. 2 lit. i) dyrektywy 2009/28/WE,

- paliwa syntetyczne i parafinowe,

- gaz ziemny, w tym biometan, w postaci gazowej (sprężony gaz ziemny - CNG) i w postaci ciekłej (skroplony gaz ziemny - LNG), oraz

- gaz płynny (LPG);”.

W przypadku biopaliw ich definicję podaje art. 2 lit. i dyrektywy 2009/28/WE (Dyrektywa 2009/28/WE): „i) «biopaliwa» oznaczają ciekłe lub gazowe paliwa dla transportu, produkowane z biomasy". 


\section{Rodzaje europejskich paliw silnikowych o znormalizowanej jakości podlegające obowiązkowemu oznakowaniu}

Europejski Komitet Normalizacyjny, którego członkiem jest Polski Komitet Normalizacyjny, opracował szereg specyfikacji jakościowych dla europejskich paliw silnikowych. Normy europejskie są wdrażane do zbioru norm krajów członkowskich, w tym do zbioru Polskich Norm. Z przeglądu dotychczas opublikowanych norm europejskich wynika, jakie rodzaje paliw silnikowych były przedmiotem prac normalizacyjnych, których podstawą były badania prowadzone w krajach Unii Europejskiej w tym zakresie.

W odniesieniu do paliw typu benzyny na rynku europejskim występują trzy rodzaje paliw do silników o zapłonie iskrowym: 1) dwa rodzaje bezołowiowej benzyny silnikowej: E5 i E10. Liczby 5 i 10 oznaczają, że benzyna może zawierać odpowiednio: albo maksymalnie $5 \%$ obj. etanolu, albo maksymalnie $10 \%$ obj. etanolu. Jakość benzyny bezołowiowej określa obecnie norma PN-EN 228+A1:2017-06 (P) - wersja polska. Warto w tym miejscu dodać, że obecnie w Polsce zarówno benzyna bezołowiowa 95, jak i benzyna bezołowiowa 98 jest benzyną E5;

2) jeden rodzaj paliwa etanolowego - E85. Liczba 85 oznacza, że paliwo to może zawierać nominalnie do $85 \%$ obj. etanolu. Jakość paliwa etanolowego określa obecnie norma PN-EN 15293:2018-09 (E) - wersja angielska. Obecnie w Polsce tego rodzaju paliwa nie ma na rynku.

Wymienione wyżej trzy rodzaje paliw silnikowych typu benzyny zawierają w swej formule etanol pozyskiwany $\mathrm{z}$ biomasy. Aby mógł on być składnikiem tych paliw, jego jakość musiała zostać odpowiednio zweryfikowana i znormalizowana. Jakość etanolu stosowanego do paliw typu benzyny określa obecnie norma PN-EN 15376:2014-11 (P) - wersja polska.

W odniesieniu do paliw typu olej napędowy na rynku europejskim występuje pięć rodzajów paliw do silników o zapłonie samoczynnym:

1) olej napędowy B7. Liczba 7 oznacza, że olej napędowy może zawierać maksymalnie 7\% obj. estrów metylowych kwasów tłuszczowych (FAME). Jego jakość określa norma PN-EN 590+A1:2017-06 (P) - wersja polska. Na rynku polskim ten olej napędowy stanowi gatunek podstawowy;

2) olej napędowy B10. Liczba 10 oznacza, że olej napędowy może zawierać maksymalnie $10 \%$ obj. estrów metylowych kwasów tłuszczowych (FAME). Jego jakość określa norma PN-EN 16734+A1:2018-12 (E) - wersja angielska. Na rynku polskim ten rodzaj oleju napędowego nie występuje;

3) olej napędowy B20/B30. Liczba 20 lub 30 oznacza, że olej napędowy może zawierać maksymalnie 20\% lub 30\% obj. estrów metylowych kwasów tłuszczowych (FAME). Jego jakość określa norma PN-EN 16709+A1:2018-12 (E) - wersja angielska. Na rynku polskim ten rodzaj oleju napędowego nie występuje;

4) olej napędowy B100. Liczba 100 oznacza, że ten rodzaj oleju napędowego jest w $100 \%$ estrami metylowymi kwasów tłuszczowych (FAME). Jego jakość określa norma PN-EN 14214+A1:2014-04 (P) - wersja polska. Olej napędowy B100 stanowi paliwo samoistne, a także składnik wszystkich wyżej wymienionych rodzajów olejów napędowego. Na rynku polskim ten rodzaj oleju napędowego obecnie nie występuje;

5) parafinowy olej napędowy XTL. Litery XTL oznaczają, że olej napędowy jest w całości pochodzenia syntetycznego lub z procesu hydrorafinacji olejów roślinnych i tłuszczów zwierzęcych. Parafinowy olej napędowy może być również stosowany jako składnik mieszanin z olejem napędowym, a jako samoistne paliwo może zawierać do 7,0\% obj. FAME. Jego jakość określa norma PN-EN 15940+A1+AC:2019-04 (E) - wersja angielska. Na rynku polskim ten rodzaj oleju napędowego nie występuje.

W odniesieniu do paliw typu gazowego, które występują na rynku europejskim, są to:

1) skroplony gaz węglowodorowy LPG. Litery LPG oznaczają skrót nazwy w języku angielskim liquid petroleum gas. Jakość tego paliwa określa norma PN-EN 589+A1:2012 (P) - wersja polska. Występuje ono w znacznym wolumenie na rynku polskim i stanowi, oprócz benzyny bezołowiowej, drugi rodzaj paliwa zasilającego pojazdy z silnikami o zapłonie iskrowym;

2) sprężony gaz ziemny / ciekły gaz ziemny CNG/LNG. Litery CNG/LNG oznaczają skrót nazw w języku angielskim compressed natural gas / liquid natural gas. Jakość tego rodzaju paliwa określa norma PN-EN 16723-2:2017-10 - wersja angielska. Na rynku polskim obecne są oba rodzaje paliw w niewielkim wolumenie. Liczba stacji tankowania CNG na terenie Polski to 23 miejsca według informacji Przemysłowego Instytutu Motoryzacji PIMOT (2018). Stacje tankowania LNG według PIMOT to 3 miejsca (2018); 3) wodór $\mathrm{H}_{2}$. Symbol $\mathrm{H} 2$ oznacza czyste paliwo wodorowe. Jakość tego paliwa określa norma ISO 14687-2:2012 (E). Norma ta nie została wdrożona do zbioru Polskich Norm. Paliwo to obecnie nie występuje na rynku polskim. Jednak według M. Szymaczka (2018) prace prowadzone przez Grupę LOTOS w ramach projektu Pure H2, finansowanego z instrumentu „Łącząc Europę”, pozwolą na uruchomienie do końca 2021 roku w Polsce dwóch punktów tankowania wodoru. 


\section{Norma europejska EN 16942:2016 jako narzędzie wdrażania dyrektywy DAFI}

Zapis dyrektywy DAFI (Dyrektywa 2014/94/UE) w art. 7 ust. 4 wskazał na możliwość opracowania przez Europejski Komitet Normalizacyjny specyfikacji, która umożliwi jednolity i właściwy sposób oznakowania paliw silnikowych na rynku europejskim: „Jeżeli normy europejskich organizacji normalizacyjnych określające specyfikacje techniczne paliwa nie zawierają przepisów w sprawie etykietowania do celów zgodności z danymi normami, [...] Komisja może - do celów jednolitego wykonywania ust. 1 i 2 - upoważnić europejskie organizacje normalizacyjne do opracowania specyfikacji etykietowania zgodności lub przyjąć akty wykonawcze określające formę graficzną, w tym kody barwne, dotyczące zgodności w odniesieniu do paliw, które wprowadzono na rynek Unii [...]”.

Biorąc pod uwagę powyższe zapisy dyrektywy (Dyrektywa 2014/94/UE), Komisja Europejska zwróciła się do CEN o opracowanie odpowiedniej specyfikacji. Działanie to znalazło odzwierciedlenie w zapisach Wprowadzenia do normy PN-EN 16942:2016: „W piśmie do CEN z dnia 26 sierpnia 2015 roku Komisja Europejska wnioskowała o podjęcie przez CEN/TC 441 prac dotyczących opracowania i wprowadzenia odpowiedniej Normy Europejskiej określającej zharmonizowane specyfikacje oznakowania w przedmiocie zgodności dla poszczególnych paliw wprowadzonych do obrotu. Zaleca się, aby postanowienia te obejmowały graficzną formę wraz ze schematem kodów kolorów. Zaleca się, aby graficzna forma była również zgodna z następującymi wymaganiami artykułu 7 dyrektywy 2014/94/UE”.

Prace nad opracowaniem projektu normy rozpoczęły się w sierpniu 2015 r. W Europejskim Komitecie Normalizacyjnym został powołany Komitet Techniczny ds. znakowania paliw (CEN, 2015). Zakres prac obejmował opracowanie projektu normy zapewniającej zharmonizowany identyfikator dystrybuowanych paliw ciekłych i gazowych. Wymagania określone w normie powinny opierać się na rzeczywistych potrzebach konsumentów odnośnie do informacji o kompatybilności paliw i pojazdów. Identyfikator powinien być prosty i łatwy do zrozumienia, zapewniając jednocześnie jasne i spójne oznakowanie obecnych i nowych paliw na rynku. Paliwa obecne na rynku to mieszaniny paliwowe na bazie ropy naftowej, paliwa syntetyczne, biopaliwa, gaz ziemny, gaz ropopochodny, paliwa na bazie biogazu oraz wodór dostarczany do zastosowań niestacjonarnych. Podczas prac CEN współpracował z Komisją Europejską oraz zainteresowanymi stronami (m.in. producentami paliw, pojazdów, urządzeń dystrybucyjnych, władzami publicznymi, przedstawicielami konsumentów).

Praca komitetu CEN/TC 441 zaowocowała publikacja w dniu 12 października 2016 r. normy EN 16942:2016 Fuels Identification of vehicle compatibility - Graphical expression for consumer information (CEN CENELEC, 2016). Do zbioru Polskich Norm norma ta została wdrożona w wersji angielskiej jako PN-EN 16942:2016-11 Paliwa-Identyfikacja zgodności pojazdu - Graficzne forma informacji dla konsumenta w dniu 8 listopada 2016 r., a wersja polska ukazała się 13 lutego 2018 r. (Polski Komitet Normalizacyjny, 2016).

\section{Działania europejskie związane z wdrażaniem postanowień art. 7 dyrektywy DAFI na podstawie EN 16942:2016}

W celu możliwie jednoczesnego wdrożenia postanowień art. 7 dyrektywy (Dyrektywa 2014/94/UE) na podstawie EN 16942:2016 we wszystkich krajach europejskich instytucje europejskie zorganizowały warsztaty na temat nowego oznakowania. Z inicjatywy CEN warsztaty FUEL LABELLING odbyły się 17 maja 2017 r. w Berlinie, w siedzibie Niemieckiego Komitetu Normalizacyjnego (DIN) (CEN/TC 19/WG 21, 2017). Z kolei z inicjatywy DG MOVE (Dyrekcja Generalna ds. Mobilności i Transportu Komisji Europejskiej) w dniu 8 września 2017 r. w Brukseli zorganizowano warsztaty na temat wdrażania dyrektywy ws. infrastruktury paliw alternatywnych w UE, ze szczególnym uwzględnieniem potrzeb użytkowników, rozwiązań finansowych i modeli biznesowych (Komisja Europejska, 2017). Kolejne działania w okresie od połowy lutego 2018 r. do 12 października 2018 r. zaowocowały równoczesnym wprowadzaniem informacji dla użytkowników i operatorów w państwach członkowskich UE. Informacje zostały podane we wszystkich językach UE na poniższych witrynach: 1) dla operatorów: http://www.fuel-identifiers.eu/docs/QAoperators-PL.pdf;

2) dla konsumentów: http://www.fuel-identifiers.eu/docs/ QA-consumers-PL.pd.

\section{Działania polskie związane z wdrażaniem postanowień art. 7 dyrektywy DAFI na podstawie EN 16942:2016}

Wdrażanie postanowień art. 7 dyrektywy DAFI do porządku prawnego Polski nastapiło poprzez przygotowanie i publikacje Ustawy z dnia 11 stycznia 2018 r. o elektromobilności i paliwach alternatywnych (Dz.U. z 2018 r. poz. 317, 1356, 2348). Między innymi w rozdziale 4 pt. Obowiązi informacyjne $w$ zakresie paliw alternatywnych ustawa określa, że: „Art. 41. 1. Informacja o rodzaju paliwa alternatywnego wykorzystywanego do napędu pojazdu samochodowego jest umieszczana: 1) w instrukcji obsługi tego pojazdu - przez producenta pojazdu samochodowego; 
2) na korkach wlewu paliwa lub gniazdach pojazdowych lub w pobliżu tych korków lub tych gniazd - przez producenta pojazdu samochodowego;

3) na terenie placówki handlowej prowadzącej sprzedaż pojazdów silnikowych - przez właściciela tej placówki" (Ustawa z 11 stycznia 2018 r.).

Dalej w ustępie 6, jest mowa, że: „6. Minister właściwy do spraw energii określi, w drodze rozporządzenia, sposób:

1) oznakowania miejsc tankowania lub ładowania pojazdu samochodowego;

2) formułowania i udostępniania informacji o możliwości ładowania lub tankowania pojazdu samochodowego paliwem alternatywnym;

3) porównywania cen paliw alternatywnych z cenami benzyny silnikowej oraz oleju napędowego - biorąc pod uwagę konieczność udzielania użytkownikom pojazdów samochodowych kompletnych informacji w zakresie paliw alternatywnych oraz zapewnienia przejrzystości danych porównywanych cen paliw" (Ustawa z 11 stycznia 2018 r.). W związku z powyższymi zapisami 12 grudnia 2018 r. powstał projekt rozporządzenia Ministra Energii w sprawie oznakowania dystrybutorów używanych na stacjach paliwowych oraz stacjach zakładowych do biopaliw ciekłych (Projekt z 12 grudnia 2018 r.) jako akt wykonawczy do Ustawy z dnia 25 sierpnia 2006 r. o biokomponentach i biopaliwach ciekłych (Dz.U. z 2018 r. poz. 1344, 1356 i 1629). W treści projektu znajduje się odniesienie do opracowanej normy „§ 1. Do oznakowania dystrybutorów używanych na stacjach paliwowych oraz stacjach zakładowych do biopaliw ciekłych stosuje się wytyczne zawarte w normie PN-EN 16942 Paliwa - Identyfikacja zgodności pojazdu - Graficzna forma informacji dla konsumenta” (Projekt z 12 grudnia 2018 r.). Oznacza to, że jej postanowienia stają się obligatoryjne.

\section{Zapisy normy PN-EN 16942:2016-11}

W przedmowie normy europejskiej i we wprowadzeniu zaznaczono, że celem normy EN 16942:2016, wdrożonej do zbioru Polskich Norm jako PN-EN 16942:2016-11 (Polski Komitet Normalizacyjny, 2016), jest wsparcie wdrożenia art. 7 dyrektywy DAFI poprzez określenie jednolitych symboli graficznych poszczególnych rodzajów paliw w zakresie kształtu, koloru, rozmiaru i kodów cyfrowo-literowych oraz miejsc, w których symbol musi być umieszczony.

Według zapisów normy PN-EN 16942:2016-11 wygląd obowiązkowego identyfikatora jest następujący:

1) kolor: czarny na białym/srebrnym tle;

2) czcionka: Arial pogrubiona;

3) kształt w zależności od rodzaju produktu:
- paliwa typu benzyny - okrąg,

- paliwa typu olej napędowy - kwadrat,

- paliwa typu gazowego - romb;

4) symbol: kombinacja cyfr i/lub liter pośrodku kształtu:

- E5, E10, E85 - paliwa typu benzyny zawierające etanol,

- B7, B10, B20, B30, B100 - paliwa typu olej napędowy zawierające FAME,

- XTL - parafinowy olej napędowy,

- LPG, CNG, LNG, H2 - paliwa gazowe.

Obowiązkowe identyfikatory paliw mają następujący wygląd (PN-EN 16942:2016-11):

Dla paliw typu benzyny:

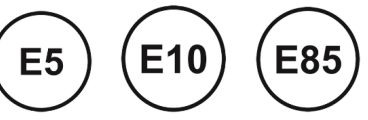

Dla paliw typu olej napędowy:

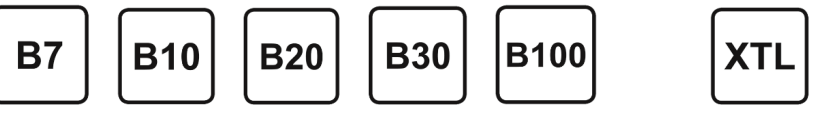

Dla paliw typu gazowego:

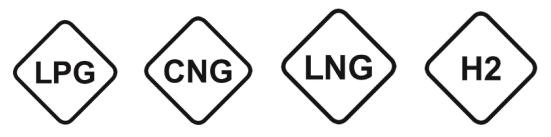

Norma PN-EN 16942:2016-11 oprócz powyższych obowiązkowych identyfikatorów określa także zharmonizowany zalecany zarys dodatkowych informacji krajowych, który jest wyborem opcjonalnym.

Na rysunkach 1 i 2 przedstawiono nowe obligatoryjne znakowanie dla oleju napędowego B7.

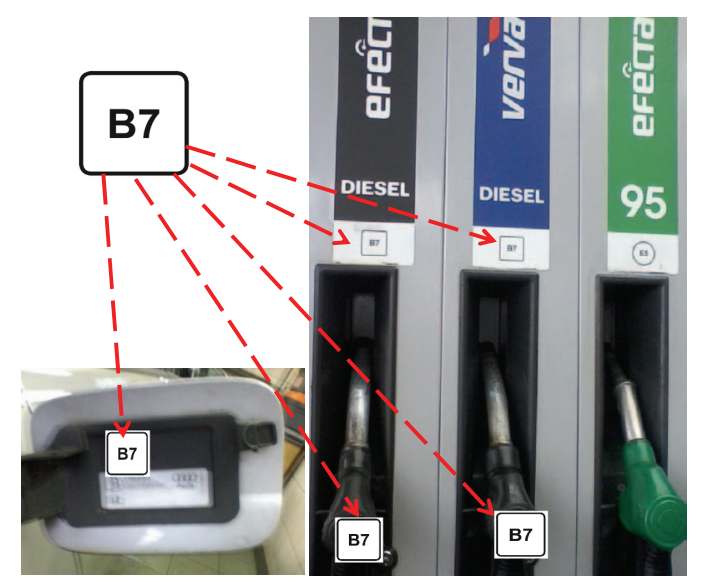

Rys. 1. Obligatoryjne znakowanie dla oleju napędowego B7 na stacji paliw (dystrybutor, pistolet wydawczy oraz klapka wlewu paliwa na pojeździe) (źródło: własne autorów)

Fig. 1. Obligatory labelling for B7 diesel fuel at filling stations (dispenser, nozzle and a fuel filler flap in the vehicle)

Oprócz znakowania dystrybutorów, pistoletów wydawczych oraz klapek wlewu paliwa w pojazdach identyczne oznakowanie pojawia się w instrukcjach obsługi pojazdów. 


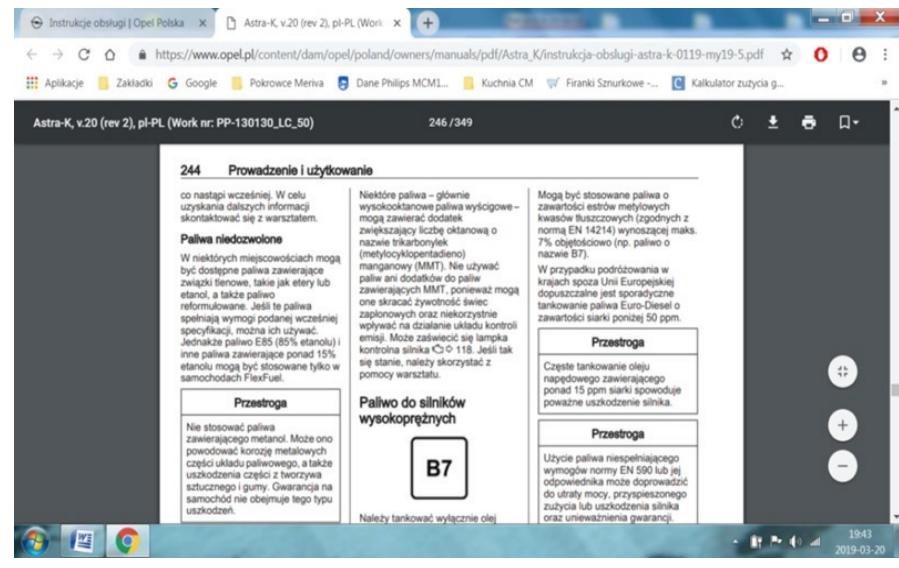

Rys. 2. Zrzut ekranu instrukcji obsługi pojazdu Opel Astra K - identyfikator oleju napędowego B7 (Opel Automobile GmbH, 2019)

Fig. 2. A screenshot of the Opel Astra K owner's manual Identifier for B7 diesel fuel (Opel Automobile GmbH, 2019)

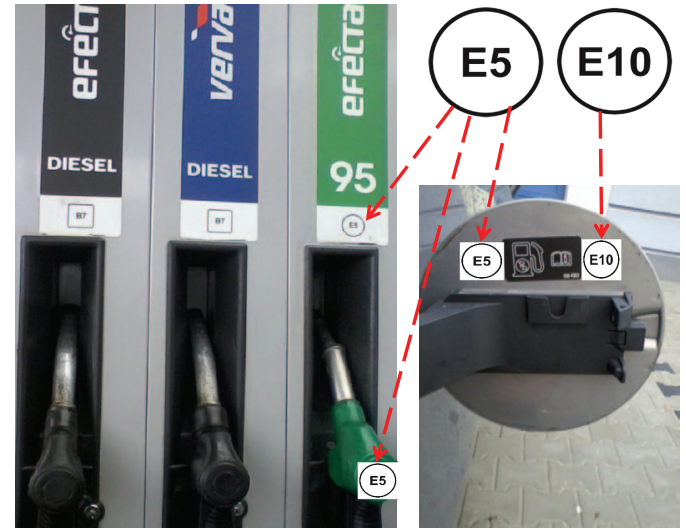

Rys. 3. Obligatoryjne znakowanie dla benzyny bezołowiowej E5 na stacji paliw (dystrybutor, pistolet wydawczy, klapka wlewu paliwa w pojeździe zasilanym benzyną E5 i E10) (źródło: własne autorów)

Fig. 3. Obligatory labelling for E5 unleaded petrol at filling stations (dispenser, nozzle and a fuel filler flap in a vehicle fueled with E5 and E10 petrol)

Przykładem jest instrukcja obsługi pojazdu Opel Astra K z identyfikatorem oleju napędowego B7 (Opel Automobile $\mathrm{GmbH}, 2019)$.

Podobnie na rysunkach 3 i 4 podano przykład nowego obligatoryjnego znakowania dla benzyny bezołowiowej E5 i E10.

Analogicznie jak w przypadku pojazdu o silniku wysokoprężnym w instrukcji obsługi pojazdu o silniku iskrowym pojawiają się identyfikatory benzyny bezołowiowej E5 i E10. W powyższym przykładzie jest to instrukcja obsługi pojazdu Opel Astra K (Opel Automobile GmbH, 2019). Warto zauważyć, że pojazdy, które są dostosowane do zasilania benzyną bezołowiową E10, mogą również tankować benzynę E5.

W przypadku gdy pojazd o zapłonie iskrowym jest przystosowany do zasilania skroplonym gazem węglowodorowym LPG, na klapce wlewu paliwa powinien pojawić się trzeci znak graficzny, jak na rysunku 5 .

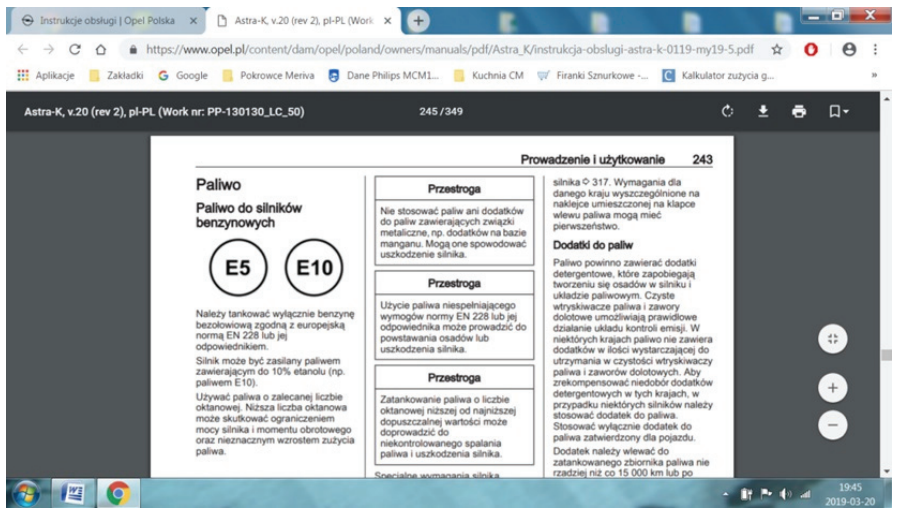

Rys. 4. Zrzut ekranu instrukcji obsługi pojazdu Opel Astra K identyfikatory benzyny bezołowiowej E5 i E10 (Opel Automobile $\mathrm{GmbH}, 2019)$

Fig. 4. A screenshot of the Opel Astra K owner's manual Identifiers of E5 and E10 unleaded petrol (Opel Automobile $\mathrm{GmbH}, 2019)$

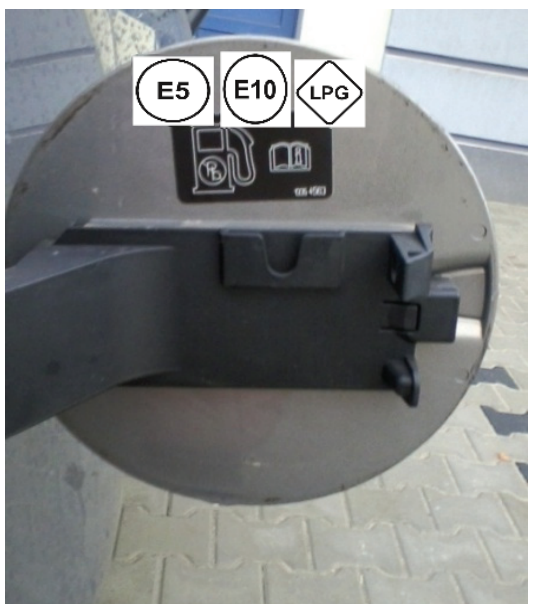

Rys. 5. Identyfikatory benzyny bezołowiowej E5, E10 oraz LPG na klapce wlewu paliwa pojazdu (źródło: własne autorów)

Fig. 5. Identifiers of unleaded E5 and E10 petrol and LPG on the fuel filler flap of the vehicle

\section{Podsumowanie}

Z powodu coraz ostrzejszych norm ochrony środowiska naturalnego i zdrowia człowieka wzrosła liczba rodzajów paliw (tradycyjne, biopaliwa, LPG, wodór, metan jako LNG lub CNG, napęd elektryczny). Do tych rodzajów paliw dostosowano konstrukcje pojazdów (nowe systemy napędowe spełniające wymagania coraz bardziej zaostrzających się norm emisji spalin EURO). Niewystarczający stał się dotychczasowy system informowania klientów. Współpraca na szczeblu KE i CEN zaowocowała opracowaniem normy europejskiej $E N$ 16942:2016 Fuels - Identification of vehicle compatibility Graphical expression for consumer information. Norma stała się podstawą do wdrażania art. 7 dyrektywy DAFI do polskiego porządku prawnego. 


\section{Literatura}

CEN, 2015. CEN creates new Project Committee on Fuel labelling. $<$ https://www.cen.eu/news/brief-news/Pages/NEWS-2015-004. aspx> (dostęp: 10.04 2019).

CEN CENELEC, 2016. Consumers filling their tanks with the right fuel thanks to new EN! https://www.cencenelec.eu/News/Press Releases/Pages/PR-2016-007.aspx (dostęp: 10.04.2019).

CEN/TC 19/WG 21, 2017. Niepublikowane dokumenty robocze.

Komisja Europejska, 2017. Workshop on alternative fuels infrastructure. $<$ https://ec.europa.eu/transport/themes/sustainable/events/2017-09-08-workshop_en> (dostęp: 12.04 2019).

Opel Automobile GmbH, 2019. Astra - instrukcja obsługi, wydanie 3, Rüsselsheim, styczeń 2019. <https://www.opel.pl/content/ dam/opel/poland/owners/manuals/pdf/Astra_K/instrukcja-obslugi-astra-k-0119-my19-5.pdf> (dostęp: 12.04.2019).

Polski Komitet Normalizacyjny, 2016. Informacje dodatkowe. $<$ http:// sklep.pkn.pl/pn-en-16942-2016-11p.html> (dostęp: 12.04.2019).

Przemysłowy Instytut Motoryzacji PIMOT, 2018. Projekt CEF Transport. Badania optymalizujące funkcjonowanie i rozmieszczenie stacji paliw alternatywnych sieci bazowej TEN-T. Lokalizacje stacji CNG LNG Polska. <http://lcng.pimot.eu/adresy-stacji-cnglng-polska/> (dostęp: 9.04.2019).

Szymaczek M., 2018. Dwie nowe stacje tankowania wodoru w Polsce. <https://www.auto-motor-i-sport.pl/wydarzenia/Dwienowe-stacje-tankowania-wodoru-w-Polsce,35451,1> (dostęp: 11.04.2019).

\section{Akta prawne i normatywne}

Dyrektywa Parlamentu Europejskiego i Rady 2009/28/WE z dnia 23 kwietnia 2009 r. w sprawie promowania stosowania energii ze źródeł odnawialnych zmieniająca i w następstwie uchylająca dyrektywy 2001/77/WE oraz 2003/30/WE (Dz. Urz. UE, 2009, L 140).

Dyrektywa Parlamentu Europejskiego i Rady 2014/94/UE z dnia 22 października 2014 r. w sprawie rozwoju infrastruktury paliw alternatywnych (Dz. Urz. UE, 2014, L 307).

ISO 14687-2:2012 Hydrogen fuel - Product specification - Part 2: Proton exchange membrane (PEM) fuel cell applications for road vehicles.
PN-EN 14214+A1:2014-04 Ciekłe przetwory naftowe - Estry metylowe kwasów tłuszczowych (FAME) do użytku w silnikach samochodowych o zapłonie samoczynnym (Diesla) i zastosowań grzewczych - Wymagania i metody badań.

PN-EN 15293:2018-09 Paliwa do pojazdów samochodowych - Paliwo etanolowe (E85) do pojazdów samochodowych - Wymagania i metody badań.

PN-EN 15376:2014-11 Paliwa do pojazdów samochodowych - Etanol jako komponent benzyny silnikowej - Wymagania i metody badań.

PN-EN 15940+A1+AC:2019-04 Paliwa do pojazdów samochodowych - Parafinowy olej napędowy z procesów syntezy lub uwodornienia - Wymagania i metody badań.

PN-EN 16709+A1:2018-12 Paliwa do pojazdów samochodowych - Olej napędowy o wysokiej zawartości FAME (B20 i B30) Wymagania i metody badań.

PN-EN 16723-2:2017-10 (E) Gaz ziemny i biometan używany w transporcie oraz biometan zatłaczany do sieci gazu ziemnego - Część 2: Specyfikacja dla paliw do pojazdów samochodowych.

PN-EN 16734+A1:2018-12 Paliwa do pojazdów samochodowych Olej napędowy B10 do pojazdów samochodowych - Wymagania i metody badań.

PN-EN 16942:2016-11 Paliwa - Identyfikacja zgodności pojazdu Graficzna forma informacji dla konsumenta.

PN-EN 228+A1:2017-06 Paliwa do pojazdów samochodowych Benzyna bezołowiowa - Wymagania i metody badań.

PN-EN 589+A1:2012 Paliwa do pojazdów samochodowych - LPG - Wymagania i metody badań.

PN-EN 590+A1:2017-06 Paliwa do pojazdów samochodowych Oleje napędowe - Wymagania i metody badań.

Projekt z dnia 12 grudnia 2018 r. Rozporządzenia Ministra Energii w sprawie oznakowania dystrybutorów używanych na stacjach paliwowych oraz stacjach zakładowych do biopaliw ciekłych. $<$ https://legislacja.rcl.gov.pl/docs//567/12320305/12565034/12 565035/dokument378302.pdf> (dostęp: 12.04 2019).

Ustawa z dnia 25 sierpnia 2006 r. o biokomponentach i biopaliwach ciekłych (Dz.U. z 2018 r. poz. 1344, 1356 i 1629).

Ustawa z dnia 11 stycznia 2018 r. o elektromobilności i paliwach alternatywnych (Dz.U. z 2018 r. poz. 317, 1356, 2348).

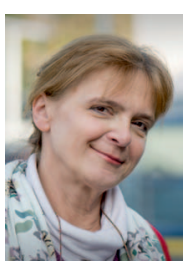

Mgr inż. Zofia BŁASZKIEWICZ

Starszy specjalista badawczo-techniczny;

kierownik Zakładu Normalizacji

Instytut Nafty i Gazu - Państwowy Instytut Badawczy

ul. Lubicz 25 A

31-503 Kraków

E-mail: zofia.blaszkiewicz@inig.pl 